\title{
Correction to: Subjective Well-Being, Transnational Families and Social Integration of Married Immigrants in Italy
}

\author{
Maria Carella $^{1}$ (D) Thaís García-Pereiro ${ }^{1}$ (D) $\cdot$ Roberta Pace $^{1}$ (D)
}

Published online: 29 September 2020

(c) Springer Nature B.V. 2020

\section{Correction to: Social Indicators Research https://doi.org/10.1007/s11205-020-02402-y}

In the original publication of the article the Acknowledgement section has been missed to include and now the same has been updated in this correction.

Acknowledgement The authors acknowledge the financial support provided by the MiuRPRIN Grant No 2017W5B55Y (GDR project "The Great Demographic Recession", PI: Daniele Vignoli).

Publisher's Note Springer Nature remains neutral with regard to jurisdictional claims in published maps and institutional affiliations.

The original article can be found online at https://doi.org/10.1007/s11205-020-02402-y.

Thaís García-Pereiro

t.garcia.pereiro@uniba.it

Maria Carella

maria.carella1@uniba.it

Roberta Pace

roberta.pace@uniba.it

1 Università degli Studi di Bari “Aldo Moro”, Bari, Italy 